\title{
Growth Performance, Bone Quality, and Phosphorus Availability in Broilers Given Phosphorus-Deficient Diets Containing Buckwheat (Fagopyrum esculentum)
}

\author{
Rakhi Chowdhury ${ }^{1}$ and Katsuki Koh ${ }^{2}$ \\ ${ }^{1}$ Interdisciplinary Graduate School of Science and Technology, Shinshu University, Minamiminowa, Nagano 399-4598, Japan \\ ${ }^{2}$ Faculty of Agriculture, Shinshu University, Minamiminowa, Nagano 399-4598, Japan
}

To determine whether buckwheat phytase can be used as an alternative phytase source, growth performance, bone quality and P retention were measured in broilers given non-phytate P-deficient diets. Non-germinated (BU) and germinated (GBU) buckwheat were used: they were ground and sieved to remove hulls before use. A total of 120 male broiler chicks ( $8 \mathrm{~d}$ of age) were divided into 8 groups ( 15 birds each) and given one of the following 8 diets until $42 \mathrm{~d}$ of age: positive control (PC) diet satisfying recommended level of all nutrients, negative control (NC) diet formulated to contain $0.16 \%$ lower non-phytate P than PC diet, and six other diets, formulated by replacing maize in NC diet with BU or GBU at $10 \%, 15 \%$ and $20 \%$ concentrations. Starter diets contained $23.5 \%$ crude protein $(\mathrm{CP})$ and $3,200 \mathrm{kcal}$ of ME$/ \mathrm{kg}$, and were used for 8-21 d of age. Then, grower diets with $20.5 \% \mathrm{CP}$ and $3,250 \mathrm{kcal}$ of ME$/ \mathrm{kg}$, and were provided for 22-42 d of age. Compared with the PC group, NC group showed impaired growth performance (BW gain, FI, and FCR), and bone quality (dry weight, breaking strength and contents of ash and P in tibia). However, in most cases, these impairments were ameliorated dose-dependently by the addition of BU and GBU in diets, and the restoration magnitude was greater in GBU than in BU treatment. Total P excretion decreased in NC group and further decreased dose-dependently with increasing levels of BU and GBU. Except for the values in PC group, total P retention increased as the total $\mathrm{P}$ excretion decreased. In conclusion, dietary BU and GBU restored the growth performance and bone quality impaired by the P deficiency, and improved P retention in broilers, which suggested that buckwheat, especially when germinated, can be used as an alternative phytase source in broiler diets.

Key words: bone quality, broilers, buckwheat, growth performance, phosphorus retention

J. Poult. Sci., 55: 249-256, 2018

\section{Introduction}

Phosphorus $(\mathrm{P})$ is one of the major nutrients in poultry excreta, and feed supplementation with microbial phytase and phytase-rich cereals have been investigated as a solution for $\mathrm{P}$ retention. Interestingly, wheat (Triticum aestivum) and triticale (Triticosecale) have a high phytase activity and can improve $\mathrm{P}$ digestibility in poultry (Barrier-Guillot et al., 1996; Jondreville et al., 2007). Moreover, this activity increases with germination, along with a concomitant decrease in phytic acid concentration (Bartnik and Szafrańska, 1987; Ma and Shan, 2002).

Buckwheat (Fagopyrum esculentum) (BU) is a nonglutinous pseudocereal, taxonomically distant from wheat

Received: October 30, 2017, Accepted: January 15, 2018

Released Online Advance Publication: March 25, 2018

Correspondence: Dr. Katsuki Koh, Faculty of Agriculture, Shinshu University, Minamiminowa, Nagano 399-4598, Japan.

(E-mail: kkkohss@shinshu-u.ac.jp) and triticale, which is produced in many countries, including Russia, China, Kazakhstan, Ukraine, France, Poland, USA and Japan. However, there is a lack of studies assessing the use of pseudocereal as a feed source, and therefore, information on its phytase content is still limited. According to our preliminary report (Chowdhury et al., 2017), buckwheat had high phytase activity which further increased after germination (GBU), but the effects of dietary BU and GBU on $\mathrm{P}$ utilization in broilers were not clarified.

To confirm whether buckwheat can be used as an alternative phytase source, we measured the growth performance, bone quality and $\mathrm{P}$ retention in broilers reared on nonphytate P-deficient diets containing BU and GBU at different levels, and discussed the efficacy of phytase from BU or GBU in broilers.

\section{Materials and Methods}

This study was conducted in accordance with the guidelines for regulation of animal experimentation of Shinshu 
University, Japan.

\section{Germination of $B U$}

Seeds of buckwheat (Shinano No. 1 variety) with high phytase activity were purchased commercially, and a proportion of these seeds were germinated following the method of Egli et al. (2002) with slight modification. In brief, the seeds were soaked in water for $12 \mathrm{~h}$ and then transferred to a tray lined with wet paper, and allowed to germinate for $36 \mathrm{~h}$ at $23 \pm 2^{\circ} \mathrm{C}$ in a dark condition. During germination, water was sprinkled on seeds every $10 \mathrm{~h}$. After germination, the seeds were dried at $50^{\circ} \mathrm{C}$ in a forced air oven for $7 \mathrm{~h}$. Both of non-germinated and germinated seeds were ground to pass through a $1.0-\mathrm{mm}$ aperture and approximately $93 \%$ of the hulls were removed by sieving whole ground seeds. Ground $\mathrm{BU}$ and GBU were kept at room temperature for further analysis (Table 1).

\section{Birds, Diets and Sampling}

One hundred and twenty, 8-d old male broiler chicks (Ross 308) were divided into eight dietary groups of 15 birds each and kept in floor pens under 24-h light condition. Each dietary group was assigned to one of the following experimental diets: a positive control (PC) diet, formulated according to the NRC (1994) recommendations, a negative control (NC) diet, formulated to contain $0.16 \%$ lower nonphytate $\mathrm{P}$ than the PC diet, and six other diets, formulated to contain $10 \%, 15 \%$ and $20 \%$ of BU or GBU in the NC diet, at the expense of maize (Tables 2 and 3). Starter diets contained $23.5 \% \mathrm{CP}$ and $3,200 \mathrm{kcal}$ of $\mathrm{ME} / \mathrm{kg}$ and were used for 8-21 d of age. Next, grower diets with $20.5 \% \mathrm{CP}$ and 3,250 $\mathrm{kcal}$ of ME $/ \mathrm{kg}$ were provided for $22-42 \mathrm{~d}$ of age. Birds were kept in floor pens from 8 to $35 \mathrm{~d}$ of age and then transferred to wire-floor cages for excreta collection. Diets and water were provided ad libitum for the 35-d experimental period (from 8 to $42 \mathrm{~d}$ of age). Feed intake (FI) and body weight (BW) were recorded daily and weekly, respectively. Feed conversion ratio (FCR) was calculated at the end of trial as the ratio of FI to weight gain ( $\mathrm{g}$ feed/g gain). Excreta were collected from 39 to $41 \mathrm{~d}$ of age and stored at $-20^{\circ} \mathrm{C}$ in a freezer. Frozen excreta samples were then thawed, homoge-

Table 1. Chemical composition of buckwheat (Shinano No. 1) ${ }^{1}$

\begin{tabular}{lcc}
\hline \multirow{2}{*}{ Components, \% } & \multicolumn{2}{c}{ Shinano No. 1 buckwheat } \\
\cline { 2 - 3 } & BU & GBU \\
\hline Crude protein & 15.26 & 17.08 \\
Ether extract & 3.17 & 3.08 \\
Crude fiber & 5.06 & 6.23 \\
Crude ash & 2.04 & 2.07 \\
Total P & 0.38 & 0.42 \\
Phytate P & 0.32 & 0.27 \\
Phytase activity, $\mathrm{PU}^{2} / \mathrm{g}$ & 2.10 & 2.60 \\
\hline
\end{tabular}

\footnotetext{
${ }^{1}$ Values based on analysis of triplicate samples (dry matter basis).

${ }^{1} \mathrm{BU}=$ non-germinated buckwheat; GBU $=$ germinated buckwheat.

${ }^{2}$ Phytase unit (PU) equivalent to the enzymatic activity, which liberates $1 \mu \mathrm{mol}$ inorganic phosphate per min at $\mathrm{pH} 5.5$ and $37^{\circ} \mathrm{C}$.
}

nized, dried, and ground before analysis.

On $43 \mathrm{~d}$ of age, 12 birds per dietary group were killed by cervical dislocation and then dressed: carcass, breast and leg meat, and internal organs (heart, spleen, liver, and gizzard) were weighed. Tibia and femur bones ( 2 tibias and 2 femurs per bird) were collected from 10 birds in each dietary group, measured in length and width, and then subjected to measurement of breaking strength $\left(\mathrm{kgf} / \mathrm{cm}^{2}\right)$ using a force gauge (ZTA-5000N, IMADA Co., Ltd., Japan). Subsequently, they were measured for dry weight after drying at $100^{\circ} \mathrm{C}$ for $24 \mathrm{~h}$, and then ashed at $600^{\circ} \mathrm{C}$ for $24 \mathrm{~h}$ (Chung and Baker, 1990). On the same day, for body composition analysis, three birds per group were killed without bleeding. After defeathering, they are ground to be homogenous and then stored at $-20^{\circ} \mathrm{C}$ until analysis.

\section{Chemical Analysis}

Samples of BU, GBU, diets, excreta, and whole body of birds were analyzed for proximate composition following the standard methods (AOAC, 1990). Total P and phytate P of the samples were measured according to ISO (1998) and Haug and Lantzsch (1983), respectively: non-phytate P was calculated by subtracting the phytate $\mathrm{P}$ from total $\mathrm{P}$.

Phytase activity was measured following the method described by Eeckhout and De Paepe (1994). Phytase acts on sodium phytate and releases inorganic P. The phytase unit was defined as the amount of phytase activity that liberates inorganic $\mathrm{P}$ from a $0.0015 \mathrm{M}$ Na-phytate solution, at a rate of $1 \mu \mathrm{mol}$ per min at $\mathrm{pH} 5.5$ and $37^{\circ} \mathrm{C}$.

\section{Calculation and Statistical Analysis}

The percentage ash was determined relative to the dry weight of the bone. Tibia weight/length index and femur weight/length index were calculated by dividing the weight by its length (Seedor et al., 1991).

Statistical significances among the dietary groups were determined using Tukey's multiple comparison tests at a significance level of 5\% after one-way ANOVA (SAS Institute, 2015). In addition, two-way ANOVA was performed by omitting the $\mathrm{PC}$ and $\mathrm{NC}$ groups to test for the main and interaction effects between the BU and GBU groups. Linear regression analysis was conducted to obtain the equations relating phytase levels in diets with response (BW gain, FI, tibia ash and tibia P) using the SAS statistical package. The linear regression model used was:

$$
\mathrm{Y}=\mathrm{a}+\mathrm{b} \times \mathrm{X}
$$

where ' $\mathrm{Y}$ ' is the response criterion, ' $\mathrm{a}$ ' is the ' $\mathrm{Y}$ ' intercept, ' $b$ ' is the slope of the response criterion and ' $\mathrm{X}$ ' is the level of phytase (PU/kg diet) from BU or GBU (calculated values were used).

\section{Results}

\section{Growth Performance and Body Composition (Table 4)}

Final BW in the birds given PC diet $(2,925 \mathrm{~g})$ was slightly lower than the corresponding value of male ROSS 308 broiler $(3,023 \mathrm{~g})$ (Aviagen, 2014). This value was further decreased by about $10 \%$ in the NC group, but restored dosedependently with the increasing levels of BU and GBU in the diets. Comparing the BU and GBU treatments, the degree of 
Table 2. Ingredients and chemical composition of the experimental diets (starter phase: 8-21 d) ${ }^{1}$

\begin{tabular}{|c|c|c|c|c|c|c|c|c|}
\hline \multirow{2}{*}{ Ingredients, \% } & \multirow{2}{*}{$\mathrm{PC}$} & \multirow{2}{*}{$\mathrm{NC}$} & \multicolumn{3}{|c|}{$\mathrm{NC}+\mathrm{BU}$} & \multicolumn{3}{|c|}{$\mathrm{NC}+\mathrm{GBU}$} \\
\hline & & & $10 \%$ & $15 \%$ & $20 \%$ & $10 \%$ & $15 \%$ & $20 \%$ \\
\hline Commercial diet ${ }^{2}$ & 55.0 & 51.0 & 51.0 & 51.0 & 51.0 & 51.0 & 51.0 & 51.0 \\
\hline Soybean meal & 20.0 & 20.7 & 20.0 & 18.8 & 17.5 & 20.0 & 18.8 & 17.5 \\
\hline Maize & 20.1 & 24.1 & 13.0 & 8.4 & 3.95 & 13.0 & 8.4 & 3.95 \\
\hline $\mathrm{BU}$ & - & - & 10.0 & 15.0 & 20.0 & - & - & - \\
\hline GBU & - & - & - & - & - & 10.0 & 15.0 & 20.0 \\
\hline Maize oil & 2.50 & 2.00 & 3.80 & 4.60 & 5.35 & 3.80 & 4.60 & 5.35 \\
\hline $\mathrm{Ca}_{3}\left(\mathrm{PO}_{4}\right)_{2}$ & 0.8 & - & - & - & - & - & - & - \\
\hline $\mathrm{CaCO}_{3}$ & 0.7 & 1.3 & 1.3 & 1.3 & 1.3 & 1.3 & 1.3 & 1.3 \\
\hline Salt & 0.3 & 0.3 & 0.3 & 0.3 & 0.3 & 0.3 & 0.3 & 0.3 \\
\hline Vit-min Premix ${ }^{3}$ & 0.6 & 0.6 & 0.6 & 0.6 & 0.6 & 0.6 & 0.6 & 0.6 \\
\hline \multicolumn{9}{|c|}{ Analyzed composition, \% (as fed basis) } \\
\hline Crude protein & 23.57 & 23.49 & 23.53 & 23.56 & 23.68 & 23.52 & 23.55 & 23.63 \\
\hline Crude fiber & 3.98 & 3.91 & 4.16 & 4.28 & 4.41 & 4.31 & 4.53 & 4.72 \\
\hline Total P & 0.74 & 0.59 & 0.59 & 0.58 & 0.58 & 0.58 & 0.59 & 0.59 \\
\hline Phytate P & 0.28 & 0.29 & 0.28 & 0.28 & 0.28 & 0.29 & 0.29 & 0.29 \\
\hline non-phytate $\mathrm{P}^{4}$ & 0.46 & 0.30 & 0.31 & 0.30 & 0.30 & 0.29 & 0.30 & 0.30 \\
\hline Calcium $^{5}$ & 0.99 & 0.99 & 1.00 & 1.00 & 1.00 & 0.99 & 1.00 & 1.00 \\
\hline ME, $\mathrm{kcal} / \mathrm{kg}^{5}$ & 3,204 & 3,207 & 3,206 & 3,209 & 3,211 & 3,206 & 3,209 & 3,211 \\
\hline $\begin{array}{l}\text { Phytase, PU/kg of diet on } \\
\text { DM basis }^{6}\end{array}$ & ND & ND & 210 & 315 & 420 & 260 & 390 & 520 \\
\hline $\begin{array}{l}{ }^{1} \mathrm{PC}=\text { positive control, } \mathrm{NC} \\
{ }^{2} \text { Broiler Starter diet }(\mathrm{CP} \geq \\
{ }^{3} \text { Vitamin-mineral premix } \\
\text { vitamin E, } 11 \mathrm{IU} \text {; vitami } \\
\text { thenic acid, } 18 \mathrm{mg} \text {; niacin } \\
\text { ganese, } 280 \mathrm{mg} \text {; iodine, } \\
{ }^{4} \text { Calculated value. } \\
{ }^{5} \text { Calculated nutrient conte } \\
{ }^{6} \text { Phytase activity value wa } \\
\text { Shinano No. } 1 \mathrm{BU} \text { and }\end{array}$ & $\begin{array}{l}\text { negative } \\
.5 \%, \mathrm{ME} \\
\text { ided witl } \\
3,1.1 \mathrm{mg} \\
5 \mathrm{mg} \text {; cho } \\
\mathrm{ng} \text {. } \\
\text { vas basec } \\
\text { lculated } \\
\mathrm{J}, \mathrm{ND}=\mathrm{r}\end{array}$ & $\begin{array}{l}\text { trol, BU } \\
, 050 \mathrm{kcal} \\
\text { e followi } \\
\text { tamin } \mathrm{B}_{1} \\
\text { chloride } \\
\text { ingredie } \\
\text { the dry } \mathrm{m} \\
\text { determin }\end{array}$ & $\begin{array}{l}\text { on-germi } \\
\text { Feedon } \\
\text { concentr } \\
\text { mg; vita } \\
700 \mathrm{mg} \text {; } \\
\text { composit } \\
\text { er basis }\end{array}$ & $\begin{array}{l}\text { ed buckw } \\
\text { o., Ltd. K } \\
\text { ns per kg } \\
\mathrm{B}_{2}, 23 \mathrm{~m} \\
\text { cin, } 2.2 \mathrm{n} \\
\text { data fron } \\
\text { e diets, }\end{array}$ & $\begin{array}{l}\text { at, GBU } \\
\text { agawa, Ja } \\
\text { diet: vitar } \\
\text { vitamin } \\
\text { iron, } 95 \\
\text { te NRC } \\
\text { h was ba }\end{array}$ & $\begin{array}{l}\text { ninated b } \\
\text { m,000 I } \\
\text { m; vitan } \\
\text { opper, } 11\end{array}$ & $\begin{array}{l}\text { wheat. } \\
\text { vitamin D } \\
\mathrm{B}_{12}, 0.02 \\
\text {; zinc, } 18\end{array}$ & $\begin{array}{l}\text {,000 IU; } \\
\text {; panto- } \\
\text { g; man- } \\
\text { tivity in }\end{array}$ \\
\hline
\end{tabular}

restoration was greater in the GBU groups than in the BU groups. BW gain showed a similar tend as the final BW. FI was decreased slightly but significantly in the $\mathrm{NC}$ and $\mathrm{BU}$ groups, however, FI did not decrease in all GBU groups. FCR in the PC group was similar to the corresponding value of male ROSS 308 broiler (Aviagen, 2014), which was deteriorated in the NC group. Although restoration of the FCR was dose-dependent in the BU groups, such a trend was not observed in the GBU groups. However, among the BU and GBU groups, the overall growth performance of $20 \% \mathrm{GBU}$ group was comparable with that of PC group.

No significant difference was found among the groups in terms of internal organs weight, carcass yield as \% live weight and meat yield as \% carcass weight (data not shown). Moisture content in the whole body of birds ranged from $68.8 \%$ to $70.9 \%$ and ash content from $2.3 \%$ to $2.6 \%$, and neither were affected by the experimental diets (data not shown). The CP content was numerically higher in the BU and GBU groups compared with the $\mathrm{PC}$ and $\mathrm{NC}$, but it did not follow any regular trend, and the EE content was almost similar in all groups.

\section{Bone Quality (Table 5 and Table 6)}

Length and width of the tibia and femur bones were not affected by the experimental diets (data not shown). All values in tibia decreased significantly in the NC group compared with the PC group, and the values were restored in most cases by the addition of BU and GBU in the diets. Non-significant differences were observed among the levels of BU and GBU in terms of dry tibia weight, tibia weight/ length index, tibia ash and $\mathrm{P}$ contents. Restoration of tibia breaking strength was dose-dependent in the BU groups, but not in the GBU groups. Similar tendency was observed in femur breaking strength. Comparing the values, the degree of restoration was greater in the GBU groups than in the BU groups. Decreased dry femur weight in the NC group was restored in the $20 \%$ GBU group. Significant difference in femur weight/length index was found for the main effect of germination, but the main effect of level was not significant. Moreover, no significant differences in femur ash and $\mathrm{P}$ contents were observed for both main effects.

\section{Balance of Total $P$ and Nitrogen (Table 7)}

Total $\mathrm{P}$ intake varied $(P<0.05)$ between the $\mathrm{PC}$ and other groups because of the varying dietary level of P. Interest- 
Table 3. Ingredients and chemical composition of the experimental diets (grower phase: 22-42 d) ${ }^{1}$

\begin{tabular}{|c|c|c|c|c|c|c|c|c|}
\hline \multirow{2}{*}{ Ingredients, \% } & \multirow{2}{*}{$\mathrm{PC}$} & \multirow{2}{*}{$\mathrm{NC}$} & \multicolumn{3}{|c|}{$\mathrm{NC}+\mathrm{BU}$} & \multicolumn{3}{|c|}{$\mathrm{NC}+\mathrm{GBU}$} \\
\hline & & & $10 \%$ & $15 \%$ & $20 \%$ & $10 \%$ & $15 \%$ & $20 \%$ \\
\hline Commercial diet ${ }^{2}$ & 46.3 & 33.0 & 33.0 & 33.0 & 33.0 & 33.0 & 33.0 & 33.0 \\
\hline Soybean meal & 23.0 & 24.5 & 23.3 & 22.9 & 21.8 & 23.3 & 22.9 & 21.8 \\
\hline Maize & 27.5 & 39.9 & 30.0 & 24.7 & 20.2 & 30.0 & 24.7 & 20.2 \\
\hline $\mathrm{BU}$ & - & - & 10.0 & 15.0 & 20.0 & - & - & - \\
\hline GBU & - & - & - & - & - & 10.0 & 15.0 & 20.0 \\
\hline Maize oil & 0.9 & 0.4 & 1.5 & 2.2 & 2.8 & 1.5 & 2.2 & 2.8 \\
\hline $\mathrm{Ca}_{3}\left(\mathrm{PO}_{4}\right)_{2}$ & 0.6 & - & - & - & - & - & - & - \\
\hline $\mathrm{CaCO}_{3}$ & 0.8 & 1.3 & 1.3 & 1.3 & 1.3 & 1.3 & 1.3 & 1.3 \\
\hline Salt & 0.3 & 0.3 & 0.3 & 0.3 & 0.3 & 0.3 & 0.3 & 0.3 \\
\hline Vit-min Premix ${ }^{3}$ & 0.6 & 0.6 & 0.6 & 0.6 & 0.6 & 0.6 & 0.6 & 0.6 \\
\hline \multicolumn{9}{|c|}{ Analyzed composition, \% (as fed basis) } \\
\hline Crude protein & 20.68 & 20.59 & 20.61 & 20.53 & 20.63 & 20.45 & 20.59 & 20.56 \\
\hline Crude fiber & 3.88 & 3.68 & 3.92 & 4.20 & 4.56 & 4.18 & 4.37 & 4.80 \\
\hline Total P & 0.67 & 0.50 & 0.50 & 0.51 & 0.51 & 0.51 & 0.50 & 0.50 \\
\hline Phytate P & 0.30 & 0.29 & 0.29 & 0.30 & 0.31 & 0.30 & 0.30 & 0.29 \\
\hline non-phytate $\mathrm{P}^{4}$ & 0.37 & 0.21 & 0.21 & 0.21 & 0.20 & 0.21 & 0.20 & 0.21 \\
\hline Calcium $^{5}$ & 0.81 & 0.83 & 0.83 & 0.84 & 0.84 & 0.83 & 0.84 & 0.83 \\
\hline ME, $\mathrm{kcal} / \mathrm{kg}^{5}$ & 3,257 & 3,268 & 3,255 & 3,244 & 3,236 & 3,255 & 3,244 & 3,236 \\
\hline $\begin{array}{l}\text { Phytase, PU/kg of diet on } \\
\text { DM basis }^{6}\end{array}$ & ND & ND & 210 & 315 & 420 & 260 & 390 & 520 \\
\hline \multicolumn{9}{|c|}{$\begin{array}{l}{ }^{1} \mathrm{PC}=\text { positive control, } \mathrm{NC}=\text { negative control, } \mathrm{BU}=\text { non-germinated buckwheat, } \mathrm{GBU}=\text { germinated buckwheat. } \\
{ }^{2} \text { Broiler grower diet }(\mathrm{CP} \geq 18.0 \% \text {, ME } \geq 3,270 \mathrm{kcal} / \mathrm{kg} \text {, Feedone Co., Ltd. Kanagawa, Japan). } \\
{ }^{3} \text { Vitamin-mineral premix provided with the following concentrations per kg of diet: vitamin } \mathrm{A}, 5,000 \mathrm{IU} \text {; vitamin } \mathrm{D}_{3}, 1,000 \mathrm{IU} \text {; } \\
\text { vitamin } \mathrm{E}, 11 \mathrm{IU} \text {; vitamin } \mathrm{K}_{3}, 1.1 \mathrm{mg} \text {; vitamin } \mathrm{B}_{1}, 6 \mathrm{mg} \text {; vitamin } \mathrm{B}_{2}, 23 \mathrm{mg} \text {; vitamin } \mathrm{B}_{6}, 8 \mathrm{mg} \text {; vitamin } \mathrm{B}_{12}, 0.02 \mathrm{mg} \text {; panto- } \\
\text { thenic acid, } 18 \mathrm{mg} \text {; niacin, } 35 \mathrm{mg} \text {; choline chloride, } 1,700 \mathrm{mg} \text {; folacin, } 2.2 \mathrm{mg} \text {; iron, } 95 \mathrm{mg} \text {; copper, } 11 \mathrm{mg} \text {; zinc, } 180 \mathrm{mg} \text {; man- } \\
\text { ganese, } 280 \mathrm{mg} \text {; iodine, } 3.4 \mathrm{mg} \text {. }\end{array}$} \\
\hline
\end{tabular}

ingly, the total $\mathrm{P}$ excretion decreased, and retention increased dose-dependently, with the addition of BU and GBU in the diets. Lowest $(P<0.05)$ excretion was observed in the $20 \%$ $\mathrm{BU}$ and GBU groups, compared with other treatments, except for $15 \%$ BU and GBU. Consequently, the retention of total $\mathrm{P}$ was found to be significantly increased in these groups. Although the intake was lower, retention of total $\mathrm{P}$ in $15 \%$ and $20 \%$ BU and GBU groups were comparable with the $\mathrm{PC}$ group. On the other hand, nitrogen intake was similar in all groups, but excretion varied considerably. Lowest $(P$ $>0.05)$ excretion of nitrogen resulted in highest $(P>0.05)$ retention in the $20 \%$ GBU group compared with the PC group.

\section{Discussion}

In the present study, the diets were formulated based on the NRC (1994) in which the nutrient specifications were slightly lower than those in "ROSS 308 nutrition specification". This may be one of the reasons of the slightly decreased final BW in PC group compared with the ROSS 308 broilers (Aviagen, 2014). The deteriorated growth performance and bone quality (tibia and femur breaking strength, tibia ash and $\mathrm{P}$ contents) in the $\mathrm{NC}$ group were restored by the addition of BU and GBU in the diets, and a nearcomplete restoration was observed in the $20 \%$ GBU group, suggesting that birds complemented the shortage of $\mathrm{P}$ in the $\mathrm{NC}$ diet with non-phytate $\mathrm{P}$ released from phytate $\mathrm{P}$ by the action of BU and GBU phytase. The degree of restoration was greater in the GBU groups than in BU groups, which could be due to the increased phytase activity by germination. It is noteworthy that $20 \%$ GBU group showed a growth performance and bone quality comparable with the PC group. This suggests that phytase activity in the $20 \%$ GBU diet may be close enough to minimize the deficiency of non-phytate $\mathrm{P}$ in this group.

The above findings lead to expectations of decreased $\mathrm{P}$ excretion in the BU and GBU groups, which were found to be true: NC group showed decreased $\mathrm{P}$ excretion because of the $\mathrm{P}$ deficient diet, and BU and GBU groups showed further decrease in the values (compared with the PC group, 23\% to $42 \%$ decrease in the BU groups, and $23 \%$ to $46 \%$ decrease in the GBU groups). The highest decrease rate (46\%) was recorded in the $20 \%$ GBU group, which was greater than the values reported by Paik (2003), who found that addition of 
Table 4. The effects of non-germinated and germinated buckwheat added diets on the growth performance and body composition of broilers ${ }^{1}$

\begin{tabular}{|c|c|c|c|c|c|c|}
\hline \multirow[b]{2}{*}{ Dietary groups } & \multicolumn{4}{|c|}{ Growth performance ${ }^{2}$} & \multicolumn{2}{|c|}{ Body composition $^{3}$} \\
\hline & FBW, g & WG, g & FI, g/bird/d & $\begin{array}{c}\text { FCR, } \\
\mathrm{g} \text { feed/g gain }\end{array}$ & $\mathrm{CP}, \%$ & EE, \% \\
\hline $\mathrm{PC}$ & $2,925 \pm 31.1^{\mathrm{a}}$ & $2,729 \pm 31.3^{\mathrm{a}}$ & $130.2 \pm 0.4^{\mathrm{ab}}$ & $1.67 \pm 0.02^{\mathrm{d}}$ & $12.1 \pm 0.3$ & $12.3 \pm 1.0$ \\
\hline $\mathrm{NC}$ & $2,614 \pm 18.6^{\mathrm{e}}$ & $2,419 \pm 17.7^{\mathrm{e}}$ & $127.5 \pm 0.2^{\mathrm{c}}$ & $1.85 \pm 0.01^{\mathrm{a}}$ & $11.9 \pm 0.7$ & $10.2 \pm 0.2$ \\
\hline $\mathrm{NC}+10 \% \mathrm{BU}$ & $2,651 \pm 22.4^{\mathrm{de}}$ & $2,457 \pm 21.6^{\mathrm{de}}$ & $128.4 \pm 0.5^{\mathrm{c}}$ & $1.83 \pm 0.0^{\mathrm{ab}}$ & $12.3 \pm 0.6$ & $10.5 \pm 0.4$ \\
\hline $\mathrm{NC}+15 \% \mathrm{BU}$ & $2,715 \pm 14.8^{\mathrm{cd}}$ & $2,520 \pm 14.8^{\mathrm{cd}}$ & $128.0 \pm 0.4^{\mathrm{c}}$ & $1.78 \pm 0.0^{\mathrm{bc}}$ & $13.1 \pm 0.3$ & $10.2 \pm 1.0$ \\
\hline $\mathrm{NC}+20 \% \mathrm{BU}$ & $2,761 \pm 16.9^{\mathrm{bc}}$ & $2,567 \pm 15.6^{\mathrm{bc}}$ & $128.6 \pm 0.3^{\mathrm{c}}$ & $1.76 \pm 0.01^{\mathrm{c}}$ & $13.4 \pm 0.8$ & $10.7 \pm 0.6$ \\
\hline $\mathrm{NC}+10 \% \mathrm{GBU}$ & $2,751 \pm 15.9^{\mathrm{bcd}}$ & $2,556 \pm 14.9^{\mathrm{bc}}$ & $128.7 \pm 0.4^{\mathrm{bc}}$ & $1.76 \pm 0.01^{\mathrm{c}}$ & $13.7 \pm 0.5$ & $11.1 \pm 0.5$ \\
\hline $\mathrm{NC}+15 \% \mathrm{GBU}$ & $2,801 \pm 24.9^{\mathrm{bc}}$ & $2,605 \pm 23.5^{\mathrm{bc}}$ & $130.2 \pm 0.2^{\mathrm{ab}}$ & $1.75 \pm 0.02^{\mathrm{c}}$ & $13.2 \pm 0.1$ & $10.2 \pm 1.2$ \\
\hline $\mathrm{NC}+20 \% \mathrm{GBU}$ & $2,830 \pm 26.7^{\mathrm{ab}}$ & $2,635 \pm 25.8^{\mathrm{ab}}$ & $130.3 \pm 0.3^{\mathrm{a}}$ & $1.73 \pm 0.02^{\mathrm{cd}}$ & $13.7 \pm 0.2$ & $10.6 \pm 0.3$ \\
\hline \multicolumn{7}{|l|}{ Main effects } \\
\hline \multicolumn{7}{|l|}{ Germination } \\
\hline $\mathrm{BU}$ & $2,709 \pm 12.6^{\mathrm{b}}$ & $2,515 \pm 12.3^{\mathrm{b}}$ & $128.3 \pm 0.2^{\mathrm{b}}$ & $1.78 \pm 0.01^{\mathrm{a}}$ & $12.9 \pm 0.3$ & $10.5 \pm 0.4$ \\
\hline GBU & $2,794 \pm 14.3^{\mathrm{a}}$ & $2,599 \pm 13.7^{\mathrm{a}}$ & $129.7 \pm 0.2^{\mathrm{a}}$ & $1.75 \pm 0.01^{\mathrm{b}}$ & $13.5 \pm 0.2$ & $10.6 \pm 0.4$ \\
\hline \multicolumn{7}{|l|}{ Level } \\
\hline $10 \%$ & $2,701 \pm 16.7^{\mathrm{b}}$ & $2,506 \pm 16.2^{\mathrm{b}}$ & $128.6 \pm 0.3^{\mathrm{b}}$ & $1.80 \pm 0.01^{\mathrm{a}}$ & $13.0 \pm 0.5$ & $10.8 \pm 0.3$ \\
\hline $15 \%$ & $2,758 \pm 16.7^{\mathrm{a}}$ & $2,563 \pm 16.2^{\mathrm{a}}$ & $129.1 \pm 0.4^{\mathrm{ab}}$ & $1.76 \pm 0.01^{\mathrm{b}}$ & $13.1 \pm 0.2$ & $10.2 \pm 0.7$ \\
\hline $20 \%$ & $2,796 \pm 17.3^{\mathrm{a}}$ & $2,601 \pm 16.6^{\mathrm{a}}$ & $129.6 \pm 0.3^{\mathrm{a}}$ & $1.75 \pm 0.01^{\mathrm{b}}$ & $13.5 \pm 0.4$ & $10.6 \pm 0.3$ \\
\hline \multicolumn{7}{|l|}{ Source of variation } \\
\hline Germination & 0.0204 & $<0.0001$ & $<0.0001$ & 0.0006 & 0.1641 & 0.7587 \\
\hline Level & 0.0008 & $<0.0001$ & 0.0363 & 0.0013 & 0.5053 & 0.7044 \\
\hline Germination $\times$ Level & 0.2680 & 0.7492 & 0.0587 & 0.2732 & 0.3651 & 0.9096 \\
\hline
\end{tabular}

${ }^{\mathrm{a}-\mathrm{e}}$ Means within a column not followed by common superscripts are different at $P<0.05$.

${ }^{1} \mathrm{PC}=$ positive control; $\mathrm{NC}=$ negative control; $\mathrm{BU}=$ non-germinated buckwheat; $\mathrm{GBU}=$ germinated buckwheat; $\mathrm{FBW}=$ final body weight; $\mathrm{WG}$ $=$ weight gain; $\mathrm{FI}=$ feed intake; $\mathrm{FCR}=$ feed conversion ratio; $\mathrm{CP}=$ crude protein; $\mathrm{EE}=$ ether extract.

${ }^{2}$ Values for each parameter represent mean \pm standard error values with 15 observations (d 8 to d 42).

${ }^{3}$ Values for each parameter represent mean \pm standard error values with three observations.

microbial (derived from Aspergillus oryzae) or plant (wheat bran) phytase $(600 \mathrm{PU} / \mathrm{kg}$ diet $)$ in a P-deficient diet could decrease the $\mathrm{P}$ excretion approximately $28 \%-30 \%$ in broilers. In addition, nitrogen retention tended to increase in the $20 \%$ GBU group, although all diets were isonitrogenous. Similar observations have been reported by Selle et al. (2003), who explained that phytate-protein complexes resistant to digestion were decreased by the action of phytase (Selle et al., 2000; Ravindran et al., 1995).

According to Takemasa et al. (1996), the phytase unit (PU) equivalent to $0.10 \%$ of non-phytate $\mathrm{P}$ was $648-1,055$ $\mathrm{PU} / \mathrm{kg}$ diet (yeast phytase, at $\mathrm{pH}$ 5.5). An equivalency of 750 $\mathrm{PU} / \mathrm{kg}$ diet of triticale phytase to $0.10 \% \mathrm{P}$ was observed in terms of final weight, feed intake, and tibiotarsi dry matter, whereas it was $0.79 \% \mathrm{P}$ in terms of tibiotarsi ash (Jondreville et al., 2007). It is mentionable that in most cases, BW gain, $\mathrm{FI}$, and bone ash were used to calculate the equivalency value (Denbow et al., 1995; Jendza et al., 2006), and linear regression was considered more accurate over quadratic or other polynomial fits (Han et al., 2009; Ribeiro Jr et al., 2016). Therefore, to express the effect of buckwheat phytase as the amount of non-phytate $\mathrm{P}$ in this study, the relationships between the levels of phytase unit and BW gain, FI, tibia ash and tibia $\mathrm{P}$ content were determined, resulting in the follow- ing regression equations were obtained:

$$
\begin{aligned}
& \mathrm{Y}_{1}=2408+0.428 \mathrm{X}, \mathrm{r}^{2}=0.86 \\
& \mathrm{Y}_{2}=127.3+0.005 \mathrm{X}, \mathrm{r}^{2}=0.63 \\
& \mathrm{Y}_{3}=35.63+0.006 \mathrm{X}, \mathrm{r}^{2}=0.96 \\
& \mathrm{Y}_{4}=7.52+0.002 \mathrm{X}, \mathrm{r}^{2}=0.87
\end{aligned}
$$

where $\mathrm{Y}_{1}=\mathrm{BW}$ gain $(\mathrm{g}), \mathrm{Y}_{2}=\mathrm{FI}\left(\mathrm{g} /\right.$ bird/day), $\mathrm{Y}_{3}=$ Tibia ash (\%), $\mathrm{Y}_{4}=$ Tibia $\mathrm{P}(\%)$ and $\mathrm{X}=$ buckwheat phytase $(\mathrm{PU} / \mathrm{kg}$ diet).

All the regression equations were significant $(P<0.05)$. Consequently, the levels of phytase unit required to obtain the same BW gain, FI, tibia ash and tibia P in the PC group were calculated to be $750,580,636$ and $745 \mathrm{PU} / \mathrm{kg}$ diet, respectively. Taking the $\mathrm{BW}$ gain as the most important parameter, $750 \mathrm{PU} / \mathrm{kg}$ diet should be included in the NC diet formulated on the basis of NRC requirement, and therefore, $470 \mathrm{PU} / \mathrm{kg}$ diet of buckwheat phytase may be equivalent to $0.10 \%$ non-phytate P: the NC diet was deficient in $0.16 \%$ non-phytate $\mathrm{P}$ compared with the PC diet.

Compared with barley, triticale, and wheat which are natural phytase sources (Barrier-Guillot et al., 1996; Juanpere et al., 2004; Jondreville et al., 2007), buckwheat may be a more suitable ingredient for poultry feed, as barley, triticale, and wheat contain high levels of $\beta$-glucans (Havrlentová and Kraic, 2006), which are indigestible polysaccharides that 
Table 5. The effects of non-germinated and germinated buckwheat added diets on tibia characteristics in broilers ${ }^{1}$

\begin{tabular}{|c|c|c|c|c|c|}
\hline Dietary groups & Dry tibia wt., $\mathrm{g}$ & $\begin{array}{l}\text { Tibia wt./length } \\
\text { index, } \mathrm{mg} / \mathrm{mm}\end{array}$ & $\begin{array}{c}\text { Tibia breaking } \\
\text { strength, } \mathrm{kgf} / \mathrm{cm}^{2}\end{array}$ & Tibia ash, $\%$ & Tibia P, \% \\
\hline $\mathrm{PC}$ & $7.84 \pm 0.22^{\mathrm{a}}$ & $78.8 \pm 2.0^{\mathrm{a}}$ & $41.97 \pm 1.53^{\mathrm{a}}$ & $39.45 \pm 0.30^{\mathrm{a}}$ & $9.01 \pm 0.18^{\mathrm{a}}$ \\
\hline $\mathrm{NC}$ & $6.68 \pm 0.14^{\mathrm{c}}$ & $67.3 \pm 1.5^{\mathrm{c}}$ & $30.08 \pm 1.26^{\mathrm{d}}$ & $35.55 \pm 0.21^{\mathrm{c}}$ & $7.38 \pm 0.08^{\mathrm{c}}$ \\
\hline $\mathrm{NC}+10 \% \mathrm{BU}$ & $6.73 \pm 0.15^{\mathrm{c}}$ & $68.0 \pm 1.7^{\mathrm{c}}$ & $31.77 \pm 1.21^{\mathrm{cd}}$ & $36.80 \pm 0.68^{\mathrm{bc}}$ & $7.93 \pm 0.23^{\mathrm{bc}}$ \\
\hline $\mathrm{NC}+15 \% \mathrm{BU}$ & $6.89 \pm 0.18^{\mathrm{bc}}$ & $69.2 \pm 1.9^{\mathrm{bc}}$ & $35.06 \pm 1.33^{\mathrm{bcd}}$ & $37.61 \pm 0.74^{\mathrm{abc}}$ & $8.25 \pm 0.19^{\mathrm{b}}$ \\
\hline $\mathrm{NC}+20 \% \mathrm{BU}$ & $7.25 \pm 0.17^{\mathrm{abc}}$ & $73.2 \pm 2.1^{\mathrm{abc}}$ & $38.71 \pm 1.47^{\mathrm{ab}}$ & $38.41 \pm 0.60^{\mathrm{ab}}$ & $8.39 \pm 0.15^{\mathrm{ab}}$ \\
\hline $\mathrm{NC}+10 \% \mathrm{GBU}$ & $7.26 \pm 0.17^{\mathrm{abc}}$ & $73.2 \pm 1.4^{\mathrm{abc}}$ & $37.31 \pm 1.11^{\mathrm{abc}}$ & $37.85 \pm 0.49^{\mathrm{abc}}$ & $8.16 \pm 0.15^{\mathrm{b}}$ \\
\hline $\mathrm{NC}+15 \% \mathrm{GBU}$ & $7.63 \pm 0.22^{\mathrm{ab}}$ & $77.0 \pm 2.2^{\mathrm{ab}}$ & $40.00 \pm 1.79^{\mathrm{ab}}$ & $38.08 \pm 0.43^{\mathrm{ab}}$ & $8.21 \pm 0.15^{\mathrm{b}}$ \\
\hline $\mathrm{NC}+20 \% \mathrm{GBU}$ & $7.94 \pm 0.24^{\mathrm{a}}$ & $80.2 \pm 2.5^{\mathrm{a}}$ & $40.72 \pm 1.37^{\mathrm{ab}}$ & $39.09 \pm 0.43^{\mathrm{ab}}$ & $8.42 \pm 0.12^{\mathrm{ab}}$ \\
\hline \multicolumn{6}{|l|}{ Main effects } \\
\hline \multicolumn{6}{|l|}{ Germination } \\
\hline $\mathrm{BU}$ & $6.95 \pm 0.10^{\mathrm{b}}$ & $70.2 \pm 1.1^{\mathrm{b}}$ & $35.18 \pm 0.91^{\mathrm{b}}$ & $37.61 \pm 0.41$ & $8.19 \pm 0.12$ \\
\hline GBU & $7.61 \pm 0.12^{\mathrm{a}}$ & $76.8 \pm 1.3^{\mathrm{a}}$ & $39.35 \pm 0.85^{\mathrm{a}}$ & $38.34 \pm 0.28$ & $8.26 \pm 0.08$ \\
\hline \multicolumn{6}{|l|}{ Level } \\
\hline $10 \%$ & $6.99 \pm 0.13^{\mathrm{b}}$ & $70.6 \pm 1.2^{\mathrm{b}}$ & $34.54 \pm 1.02^{\mathrm{b}}$ & $37.32 \pm 0.44$ & $8.04 \pm 0.14$ \\
\hline $15 \%$ & $7.26 \pm 0.16^{\mathrm{ab}}$ & $73.1 \pm 1.7^{\mathrm{ab}}$ & $37.54 \pm 1.22^{\mathrm{ab}}$ & $37.84 \pm 0.44$ & $8.23 \pm 0.12$ \\
\hline $20 \%$ & $7.60 \pm 0.16^{\mathrm{a}}$ & $76.7 \pm 1.8^{\mathrm{a}}$ & $39.72 \pm 1.01^{\mathrm{a}}$ & $38.75 \pm 0.39$ & $8.40 \pm 0.09$ \\
\hline \multicolumn{6}{|l|}{ Source of variation } \\
\hline Germination & 0.0001 & 0.0001 & 0.0006 & 0.1486 & 0.6060 \\
\hline Level & 0.0108 & 0.0126 & 0.0021 & 0.0674 & 0.1332 \\
\hline Germination $\times$ Level & 0.8491 & 0.7973 & 0.4057 & 0.8878 & 0.7270 \\
\hline
\end{tabular}

${ }^{\mathrm{a}-\mathrm{d}}$ Means within a column not followed by common superscripts are different at $P<0.05$.

${ }^{1} \mathrm{PC}=$ positive control; $\mathrm{NC}=$ negative control; $\mathrm{BU}=$ non-germinated buckwheat; $\mathrm{GBU}=$ germinated buckwheat.

${ }^{1}$ Values for each parameter represent mean \pm standard error values with 10 observations.

Table 6. The effects of non-germinated and germinated buckwheat added diets on femur characteristics in broilers ${ }^{1}$

\begin{tabular}{|c|c|c|c|c|c|}
\hline Dietary groups & Dry femur wt., g & $\begin{array}{l}\text { Femur wt./length } \\
\text { index, } \mathrm{mg} / \mathrm{mm}\end{array}$ & $\begin{array}{l}\text { Femur breaking } \\
\text { strength, } \mathrm{kgf} / \mathrm{cm}^{2}\end{array}$ & Femur ash, \% & Femur P, \% \\
\hline $\mathrm{PC}$ & $6.20 \pm 0.16^{\mathrm{a}}$ & $84.2 \pm 2.3$ & $37.11 \pm 1.19^{\mathrm{a}}$ & $37.24 \pm 0.50$ & $7.46 \pm 0.14$ \\
\hline $\mathrm{NC}$ & $5.54 \pm 0.13^{\mathrm{b}}$ & $75.5 \pm 2.0$ & $27.45 \pm 1.13^{\mathrm{b}}$ & $34.46 \pm 0.62$ & $6.88 \pm 0.15$ \\
\hline $\mathrm{NC}+10 \% \mathrm{BU}$ & $5.66 \pm 0.09^{\mathrm{ab}}$ & $77.2 \pm 1.3$ & $28.20 \pm 0.79^{\mathrm{b}}$ & $35.34 \pm 0.62$ & $7.12 \pm 0.21$ \\
\hline $\mathrm{NC}+15 \% \mathrm{BU}$ & $5.82 \pm 0.10^{\mathrm{ab}}$ & $79.3 \pm 1.6$ & $33.78 \pm 0.80^{\mathrm{a}}$ & $35.27 \pm 0.80$ & $7.23 \pm 0.28$ \\
\hline $\mathrm{NC}+20 \% \mathrm{BU}$ & $6.07 \pm 0.17^{\mathrm{ab}}$ & $82.5 \pm 2.3$ & $34.40 \pm 1.09^{\mathrm{a}}$ & $36.32 \pm 0.36$ & $7.36 \pm 0.27$ \\
\hline $\mathrm{NC}+10 \% \mathrm{GBU}$ & $5.95 \pm 0.17^{\mathrm{ab}}$ & $81.2 \pm 2.6$ & $34.19 \pm 0.70^{\mathrm{a}}$ & $35.07 \pm 0.38$ & $7.04 \pm 0.20$ \\
\hline $\mathrm{NC}+15 \% \mathrm{GBU}$ & $6.11 \pm 0.14^{\mathrm{ab}}$ & $83.2 \pm 1.9$ & $36.61 \pm 1.45^{\mathrm{a}}$ & $35.86 \pm 0.85$ & $7.34 \pm 0.15$ \\
\hline $\mathrm{NC}+20 \% \mathrm{GBU}$ & $6.16 \pm 6.16^{\mathrm{a}}$ & $84.2 \pm 1.6$ & $36.72 \pm 1.46^{\mathrm{a}}$ & $36.07 \pm 0.73$ & $7.30 \pm 0.13$ \\
\hline \multicolumn{6}{|l|}{ Main effects } \\
\hline \multicolumn{6}{|l|}{ Germination } \\
\hline $\mathrm{BU}$ & $5.85 \pm 0.08^{\mathrm{b}}$ & $79.67 \pm 1.09^{\mathrm{b}}$ & $32.14 \pm 0.72^{b}$ & $35.64 \pm 0.37$ & $7.24 \pm 0.15$ \\
\hline GBU & $6.07 \pm 0.08^{\mathrm{a}}$ & $82.87 \pm 1.18^{\mathrm{a}}$ & $35.84 \pm 0.73^{\mathrm{a}}$ & $35.67 \pm 0.41$ & $7.23 \pm 0.09$ \\
\hline \multicolumn{6}{|l|}{ Level } \\
\hline $10 \%$ & $5.80 \pm 0.10$ & $79.19 \pm 1.51$ & $31.22 \pm 0.85^{\mathrm{b}}$ & $35.21 \pm 0.37$ & $7.08 \pm 0.15$ \\
\hline $15 \%$ & $5.97 \pm 0.09$ & $81.25 \pm 1.28$ & $35.19 \pm 0.87^{\mathrm{a}}$ & $35.56 \pm 0.60$ & $7.29 \pm 0.16$ \\
\hline $20 \%$ & $6.12 \pm 0.09$ & $83.37 \pm 1.39$ & $35.56 \pm 0.92^{\mathrm{a}}$ & $36.20 \pm 0.42$ & $7.33 \pm 0.15$ \\
\hline \multicolumn{6}{|l|}{ Source of variation } \\
\hline Germination & 0.0449 & 0.0495 & 0.0001 & 0.9631 & 0.9586 \\
\hline Level & 0.0711 & 0.1123 & 0.0002 & 0.3497 & 0.4964 \\
\hline Germination $\times$ Level & 0.6906 & 0.0731 & 0.2074 & 0.7747 & 0.8968 \\
\hline
\end{tabular}

${ }^{\mathrm{a}-\mathrm{b}}$ Means within a column not followed by common superscripts are different at $P<0.05$.

${ }^{1} \mathrm{PC}=$ positive control; $\mathrm{NC}=$ negative control; $\mathrm{BU}=$ non-germinated buckwheat; $\mathrm{GBU}=$ germinated buckwheat.

${ }^{1}$ Values for each parameter represent mean \pm standard error values with 10 observations. 
Table 7. The effects of non-germinated and germinated buckwheat added diets on the balance of total phosphorus and nitrogen in broilers ${ }^{1}$

\begin{tabular}{|c|c|c|c|c|c|c|}
\hline \multirow[b]{2}{*}{ Dietary groups } & \multicolumn{3}{|c|}{ Total phosphorus } & \multicolumn{3}{|c|}{ Nitrogen } \\
\hline & $\begin{array}{l}\text { Intake, } \\
\text { g/bird/d }\end{array}$ & $\begin{array}{l}\text { Excretion, } \\
\text { g/bird/d }\end{array}$ & $\begin{array}{l}\text { Retention, } \\
\text { g/bird/d }\end{array}$ & $\begin{array}{l}\text { Intake, } \\
\mathrm{g} / \text { bird/d }\end{array}$ & $\begin{array}{l}\text { Excretion, } \\
\text { g/bird/d }\end{array}$ & $\begin{array}{l}\text { Retention, } \\
\text { g/bird/d }\end{array}$ \\
\hline $\mathrm{PC}$ & $1.35 \pm 0.01^{\mathrm{a}}$ & $0.74 \pm 0.04^{\mathrm{a}}$ & $0.61 \pm 0.03^{\mathrm{a}}$ & $6.59 \pm 0.07$ & $2.88 \pm 0.09^{\mathrm{ab}}$ & $3.72 \pm 0.04^{\mathrm{abc}}$ \\
\hline $\mathrm{NC}$ & $0.98 \pm 0.01^{\mathrm{b}}$ & $0.58 \pm 0.02^{\mathrm{b}}$ & $0.39 \pm 0.03^{\mathrm{b}}$ & $6.43 \pm 0.04$ & $3.08 \pm 0.12^{\mathrm{a}}$ & $3.35 \pm 0.13^{\mathrm{c}}$ \\
\hline $\mathrm{NC}+10 \% \mathrm{BU}$ & $0.97 \pm 0.01^{\mathrm{b}}$ & $0.57 \pm 0.02^{\mathrm{bc}}$ & $0.41 \pm 0.02^{\mathrm{b}}$ & $6.45 \pm 0.08$ & $2.95 \pm 0.06^{\mathrm{a}}$ & $3.50 \pm 0.13^{\mathrm{bc}}$ \\
\hline $\mathrm{NC}+15 \% \mathrm{BU}$ & $1.00 \pm 0.01^{\mathrm{b}}$ & $0.51 \pm 0.02^{\mathrm{bcd}}$ & $0.50 \pm 0.01^{\mathrm{ab}}$ & $6.54 \pm 0.07$ & $2.89 \pm 0.08^{\mathrm{ab}}$ & $3.65 \pm 0.08^{\mathrm{abc}}$ \\
\hline $\mathrm{NC}+20 \% \mathrm{BU}$ & $1.00 \pm 0.01^{\mathrm{b}}$ & $0.43 \pm 0.02^{\mathrm{d}}$ & $0.57 \pm 0.02^{\mathrm{a}}$ & $6.48 \pm 0.07$ & $2.62 \pm 0.10^{\mathrm{ab}}$ & $3.85 \pm 0.09^{\mathrm{ab}}$ \\
\hline $\mathrm{NC}+10 \% \mathrm{GBU}$ & $1.00 \pm 0.01^{\mathrm{b}}$ & $0.57 \pm 0.03^{\mathrm{bc}}$ & $0.43 \pm 0.02^{\mathrm{b}}$ & $6.43 \pm 0.08$ & $2.99 \pm 0.10^{\mathrm{a}}$ & $3.44 \pm 0.13^{\mathrm{bc}}$ \\
\hline $\mathrm{NC}+15 \% \mathrm{GBU}$ & $1.00 \pm 0.01^{\mathrm{b}}$ & $0.44 \pm 0.04^{\mathrm{cd}}$ & $0.56 \pm 0.04^{\mathrm{a}}$ & $6.58 \pm 0.06$ & $2.74 \pm 0.13^{\mathrm{ab}}$ & $3.85 \pm 0.13^{\mathrm{ab}}$ \\
\hline $\mathrm{NC}+20 \% \mathrm{GBU}$ & $0.98 \pm 0.01^{\mathrm{b}}$ & $0.40 \pm 0.01^{\mathrm{d}}$ & $0.58 \pm 0.02^{\mathrm{a}}$ & $6.53 \pm 0.06$ & $2.46 \pm 0.07^{\mathrm{b}}$ & $4.07 \pm 0.07^{\mathrm{a}}$ \\
\hline \multicolumn{7}{|l|}{ Main effects } \\
\hline \multicolumn{7}{|l|}{ Germination } \\
\hline BU & $0.99 \pm 0.01$ & $0.50 \pm 0.01$ & $0.49 \pm 0.02$ & $6.49 \pm 0.04$ & $2.82 \pm 0.06$ & $3.66 \pm 0.68$ \\
\hline GBU & $0.99 \pm 0.01$ & $0.47 \pm 0.02$ & $0.52 \pm 0.02$ & $6.52 \pm 0.04$ & $2.73 \pm 0.08$ & $3.79 \pm 0.79$ \\
\hline \multicolumn{7}{|l|}{ Level } \\
\hline $10 \%$ & $0.98 \pm 0.01$ & $0.57 \pm 0.02^{\mathrm{a}}$ & $0.42 \pm 0.02^{\mathrm{b}}$ & $6.44 \pm 0.06$ & $2.97 \pm 0.06^{\mathrm{a}}$ & $3.47 \pm 0.08^{\mathrm{b}}$ \\
\hline $15 \%$ & $0.99 \pm 0.01$ & $0.47 \pm 0.02^{\mathrm{b}}$ & $0.53 \pm 0.02^{\mathrm{a}}$ & $6.50 \pm 0.05$ & $2.81 \pm 0.08^{\mathrm{a}}$ & $3.75 \pm 0.09^{\mathrm{a}}$ \\
\hline $20 \%$ & $1.00 \pm 0.01$ & $0.42 \pm 0.01^{\mathrm{b}}$ & $0.57 \pm 0.01^{\mathrm{a}}$ & $6.56 \pm 0.05$ & $2.54 \pm 0.06^{\mathrm{b}}$ & $3.96 \pm 0.07^{\mathrm{a}}$ \\
\hline Source of variation & \multicolumn{6}{|c|}{ 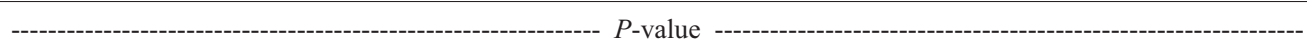 } \\
\hline Germination & 0.9659 & 0.7844 & 0.1332 & 0.6612 & 0.2499 & 0.1757 \\
\hline Level & 0.4267 & 0.0077 & $<0.0001$ & 0.3001 & 0.0004 & 0.0002 \\
\hline Germination $\times$ Level & 0.0771 & 0.6495 & 0.5139 & 0.8820 & 0.5118 & 0.3736 \\
\hline
\end{tabular}

\footnotetext{
${ }^{\mathrm{a}-\mathrm{d}}$ Means within a column not followed by common superscripts are different at $P<0.05$.

${ }^{1} \mathrm{PC}=$ positive control; $\mathrm{NC}=$ negative control; $\mathrm{BU}=$ non-germinated buckwheat; $\mathrm{GBU}=$ germinated buckwheat.

${ }^{1}$ Values for each parameter represent mean \pm standard error values with eight observations.
}

decrease nutrient digestibility (He et al., 2003; Wang et al., 2005; Moharrery, 2006), but are found in relatively low concentrations in buckwheat (Havrlentová et al., 2011). Although buckwheat has not yet been produced for animal feed to our knowledge, low quality seeds unsuitable for human consumption may probably be used for this purpose.

In conclusion, it was clarified that dietary addition of buckwheat restored the growth performance, bone quality and $\mathrm{P}$ retention impaired by $\mathrm{P}$ deficiency in broilers, and the restoration magnitude was greater in GBU than in BU treatments, suggesting that buckwheat, especially when germinated, can be used as an alternative phytase source, by partial replacement of diets deficient in non-phytate $\mathrm{P}$.

\section{Conflicts of Interest}

The authors declare no conflict of interest.

\section{References}

Association of Official Analytical Chemists. Official Method of Analysis. $15^{\text {th }}$ edition. Association of Analytical Chemists, Washington, DC. 1990.

Aviagen. Ross 308 Broiler: performance objectives. Ross Breeders Limited, Newbridge, Midlothian, EH28 8SZ, Scotland, UK. 2014.

Barrier-Guillot B, Casado P, Maupetit P, Jondreville C, Gatel F and Larbier M. Wheat phosphorus availability: 2-In vivo study in broilers and pigs; relationship with endogenous phytasic activity and phytic phosphorus content in wheat. Journal of the Science of Food and Agriculture, 70: 69-74. 1996.

Bartnik M and Szafrańska I. Changes in phytate content and phytase activity during the germination of some cereals. Journal of Cereal Science, 5: 23-28. 1987.

Chowdhury R, Rahman M and Koh K. Evaluation of buckwheat (Fagopyrum esculentum) intrinsic phytase activity to improve phosphorus availability in broilers. Journal of Advance Agricultural Technologies, 4: 82-86. 2017.

Chung TK and Baker DH. Phosphorus utilization in chicks fed hydrated sodium calcium aluminosilicate. Journal of Animal Science, 68: 1992-1998. 1990.

Denbow DM, Ravindran V, Kornegay ET, Yi Z and Hulet RM. Improving phosphorus availability in soybean meal for broilers by supplemental phytase. Poultry Science, 74: 1831-1842. 1995.

Eeckhout W and De Paepe M. Total phosphorus, phytate-phosphorus and phytase activity in plant feedstuffs. Animal Feed Science and Technology, 47: 19-29. 1994.

Egli I, Davidsson L, Juillerat MA, Barclay D and Hurrell RF. The influence of soaking and germination on the phytase activity and phytic acid content of grains and seeds potentially useful for complementary feeding. Journal of Food Science, 67: 3484-3488. 2002.

Han JC, Yang XD, Qu HX, Xu M, Zhang T, Li WL, Yao JH, Liu YR, Shi BJ, Zhou ZF and Feng XY. Evaluation of equivalency values of microbial phytase to inorganic phosphorus in 22- to 
42-day-old broilers. Journal of Applied Poultry Research, 18: 707-715. 2009.

Haug W and Lantzsch HJ. Sensitive method for the rapid determination of phytate in cereals and cereal products. Journal of the Science of Food and Agriculture, 34: 1423-1426. 1983.

Havrlentová $\mathrm{M}$ and Kraic J. Content of $\beta$-D-glucan in cereal grains. Journal of Food and Nutrition Research, 45: 97-103. 2006.

Havrlentová M, Petruláková Z, Burgárová A, Gago F, Hlinková A and Šturdík E. Cereal $\beta$-glucans and their significance for the preparation of functional foods - a review. Czech Journal of Food Science, 29: 1-14. 2011.

He T, Thacker PA, McLeod JG and Campbell GL. Performance of broiler chicks fed normal and low viscosity rye or barley with or without enzyme supplementation. Asian-Australasian Journal of Animal Sciences, 16: 234-238. 2003.

ISO. Animal feeding stuffs-Determination of phosphorus contentSpectrometric method. Ref. No ISO 6491: 1998 (E). International Standard ISO 6491 was prepared by the Technical committee ISO/TC 34, Agricultural food products subcommittee SC 10, Animal feeding stuffs. ISO, Geneva, Switzerland. 1998.

Jendza JA, Dilger RN, Sands JS and Adeola O. Efficacy and equivalency of an Escherichia coli-derived phytase for replacing inorganic phosphorus in the diets of broiler chickens and young pigs. Journal of Animal Science, 84: 3364-3374. 2006.

Jondreville C, Genthon C, Bouguennec A, Carre B and Nys Y. Characterisation of European varieties of triticale with special emphasis on the ability of plant phytase to improve phytate phosphorus availability to chickens. British Poultry Science, 48: 678-689. 2007.

Juanpere J, Pérez-Vendrell AM and Brufau J. Effect of microbial phytase on broilers fed barley-based diets in the presence or not of endogenous phytase. Animal Feed Science and Technology, 115: 265-279. 2004.

Ma X and Shan A. Effect of germination and heating on phytase activity in cereal seeds. Asian-Australasian Journal of Animal Sciences, 15: 1036-1039. 2002.

Moharrery A. Comparison of performance and digestibility characteristics of broilers fed diets containing treated hulled barley or hulless barley. Czech Journal of Animal Science, 51: 122131. 2006.

NRC. Nutrient Requirements of Poultry. $9^{\text {th }}$ Revised Edition. National Academic Press, Washington, DC. 1994.

Paik I. Application of phytase, microbial or plant origin, to reduce phosphorus excretion in poultry production. Asian-Australasian Journal of Animal Sciences, 16: 124-135. 2003.

Ravindran V, Bryden WL and Kornegay ET. Phytates: occurrence, bioavailability and implications in poultry nutrition. Poultry and Avian Biology Reviews, 6: 125-143. 1995.

Ribeiro Jr V, Salguero SC, Gomes G, Barros VRSM, Silva DL, Barreto SLT, Rostagno HS, Hannas MI and Albino LFT. Efficacy and phosphorus equivalency values of two bacterial phytases (Escherichia coli and Citrobacter braakii) allow the partial reduction of dicalcium phosphate added to the diets of broilers chickens from 1 to 21 days of age. Animal Feed Science and Technology, 221: 226-233. 2016.

SAS Institute Inc. SAS/ILM ${ }^{\circledR} 14.1$ User's Guide. SAS Institute Inc. Cary, NC, USA. 2015.

Seedor JG, Quarruccio HA and Thompson DD. The biophosphonate alendronate (MK-217) inhibits bone loss due to ovariectomy in rats. Journal of Bone and Mineral Research, 6: 399-346. 1991.

Selle PH, Ravindran V, Caldwell RA and Bryden WL. Phytate and phytase: consequences for protein utilisation. Nutrition Research Reviews, 13: 255-278. 2000.

Selle PH, Ravindran V, Ravindran G, Pittolo PH and Bryden WL. Influence of phytase and xylanase supplementation on growth performance and nutrient utilisation of broilers offered wheatbased diets. Asian-Australasian Journal of Animal Sciences, 16: 394-402. 2003.

Takemasa M, Murakami H and Yamazaki M. Reduction of phosphorus excretion of chicks by addition of yeast phytase. Japanese Poultry Science, 33: 104-111. 1996. (in Japanese with English summary)

Wang ZR, Qiao SY, Lu WQ and Li DF. Effects of enzyme supplementation on performance, nutrient digestibility, gastrointestinal morphology, and volatile fatty acid profiles in the hindgut of broilers fed wheat-based diets. Poultry Science, 84: 875-881. 2005. 